\title{
THE CONCEPTUAL FOUR-SECTOR MODEL OF DEVELOPMENT OF THE COGNITIVE PROCESS DIMENSIONS IN ABSTRACT VISUAL THINKING
}

\author{
Kateřina Berková, Kristýna Krejčová, Alena Králová, \\ Pavel Krpálek, Katarína Krpálková Krelová, Dana Kolářová \\ University of Economics, Prague, Czech Republic \\ E-mail: katerina.berkova@vse.cz, kristyna.krejcova@vse.cz, kralova@vse.cz, \\ krpp01@vse.cz, katarina.krelova@vse.cz, kolard@vse.cz
}

\begin{abstract}
The research deals with the development of cognitive process dimensions in economic education. The aim is to research factors that influence academic achievement of students according to their intellectual level and grades. The researchers used quantitative design of research based on standardized assessment of intelligence and non-standardized questionnaire. The questionnaire was used to analyse the pedagogical competences of the teachers of economic subjects from the students' point of view in close relation to the teaching management and the impact on the motivation to learn and the achievement of students in these subjects. The respondents were 277 Czech students aged 16-17 who were divided into groups according to their intellectual level and grades. The data were analysed by a correlation analysis and a multiple regression model. In conclusion, the following can be stated: (a) From the point of view of the above average intelligent students, expertise can be considered as an important competency of the teacher; teaching average intelligent students, communication and presentation skills seem to be important. (b) It is desirable to develop cognitive processes, critical thinking actively, to lead students to become aware of changes in their own thinking and to orient them towards mastery goals. (c) Particularly for students with weaker results it is necessary to create intrinsic motivation, which develops cognition and thus is able to develop higher cognitive dimensions further. The links between these areas are of utmost importance for education and, above all, for developing of students' scholarship. Each student can be educated, and it is necessary to influence them to develop their personality and all of their potential abilities. The conceptual four-sector model represents the initial pathway to lead students who are differentiated according to the intellectual level and academic achievement to the active development of thinking, learning and critical insight.
\end{abstract}

Keywords: cognitive process dimensions, abstract visual thinking, intellectual level, motivation to learn, academic achievement.

\section{Introduction}

As a result of social and technological development, the needs of the so-called generation $\mathrm{Z}$ are changing in the education process. Because of the almost permanent access to the Internet, they have a large number of attractive information, which they often understand only in a superficial way. They mainly need to understand how the acquired theory is helping them solve practical problems. This generally applies to the $E-R-R$ (Evocation - Realization of Meaning - Reflection) model of learning and thinking, which is based on pedagogical constructivism (Steel, Meredith, Temple \& Walter, 1997). The three-stage model is based on the learning process, which is also focused on the active development of cognitive processes through using problem solving methods. Constructivist teaching is widespread and recommended for its positive impact on the development of motivation to learn or even on scientific way of learning 
Kateřina BERKOVÁ, Kristýna KREJČOVÁ, Alena KRÁLOVÁ, Pavel KRPÁLEK, Katarína KRPÁLKOVÁ KRELOVÁ, Dana KOLÁŘOVÁ. The conceptual four-sector model of development of the cognitive process dimensions in abstract visual thinking

PROBLEMS

OF EDUCATION

IN THE $21^{\text {st }}$ CENTURY Vol. 76, No. 2, 2018

122

(Banchi \& Bell, 2008; Cetin-Dindar, 2012). Therefore, the mentioned model of learning and thinking is a very good way to raise students' interest in learning and even in developing higher cognitive levels. The ways of developing thinking and learning that are part of this model such as Evocation - Realization of Meaning of the information - Reflection encourage students to think practically, gain experience; the application of the model develops the ability to analyse, solve real problems and think critically, but it also strengthens social competence, builds communication skills, and improves learning strategies. The application of the $E-R$ $R$ thinking and learning model in the learning process begins with using of the analysis and problem-solving method. Once students find the connection between scientific problems and daily activities and understand their importance, their motivation increases (Barrett \& Moore, 2012; Savin-Baden, 2004).

Let's pose a question: Can this way of developing thinking and active learning guarantee improving of academic achievement? According to research focused on the relation among metacognition, goal orientation and academic achievement (Gul \& Shehzad, 2012, p. 1867), it was found that target orientation (mastery goals with focus on challenges, solutions or performance goals oriented on better grades and avoidance of ambiguous challenges) does not affect academic (school) performance, as well as developed metacognitive skills have no impact on academic achievement as well. The poor relation between academic achievement and goal orientation is explained by the researchers by the fact that the students' answers concerning perceived goals in questionnaires differed from their real goals. The other reason may include that GPA (grade point average) was used for measuring academic achievement, although it gives information about academic achievement, however it might not be true measure of learning. Research (Al-Baddareen, Ghaith \& Akour, 2015) has shown that students who are interested in having a deeper understanding of information show higher academic motivation than students who want to have a good test result. Students with mastery goals have more developed metacognitive strategies that allow them to penetrate deeper into information, which increases their academic motivation.

Taking into account the fact that pedagogical constructivism and development of metacognition are not so widely used in secondary education, the researchers are therefore posing a fundamental question (Berková, Králová \& Krejčová, 2017; Berková \& Krpálek, 2017): For which students of economic branches, depending on their age, intellectual level and current study results, are pedagogical constructivism and meta-cognitive strategies appropriate for and for which they are not? The aim of the research is to build a conceptual four-sector model for the development of cognitive process dimensions in abstract-visual thinking in the concept of pedagogical constructivism, revised Bloom's taxonomy (Anderson \& Kratwohl, 2001) and the Higher-Order Cognitive Skills model (Zoller, 2015). The researchers' proposed model is built on the research approach to the educational needs of secondary education students taking into account their intellectual level, real economic skills and factors influencing academic achievement and motivation to study economic subjects. The model can therefore be helpful for the work of a teacher of economic subjects by using differentiation of students according to their study prerequisites, with a certain guarantee of improving students' academic achievement and increasing the motivation potential of the given economic subject.

One of the important cognitive processes for learning is thinking. The idea is proved by generally accepted definition of learning: Learning is any relatively permanent change in actual or potential behaviour of an individual that occurs as a result of experience. Cognitive approaches to learning focus mainly on the changes in thought that are part of learning (Sternberg \& Williams, 2010). Generally speaking, for developing of thinking, the main pillar are economic theories - not only for building economic thinking but mainly logical thinking. Their use is therefore timeless and interdisciplinary. Sociological sciences based on analogy of economic sciences (Mäki, 1992) can be used as an example as well as the theory of teaching uses the interpretation of methods of economic science. According to the authors dealing with economics and cognitive psychology (Jurečka, 2003; Sternberg \& Williams, 2010), when 
Kateřina BERKOVÁ, Kristýna KREJČOVÁ, Alena KRÁLOVÁ, Pavel KRPÁLEK, Katarína KRPÁLKOVÁ KRELOVÁ, Dana KOLÁŘOVÁ. The conceptual four-sector model of development of the cognitive process dimensions in abstract visual thinking

speaking about these methods the authors have in mind in particular (a) abstraction, which makes it possible to distinguish between substantial and insignificant and enables the object of investigation to make the analysis available; (b) an analysis that allows the complex to be divided into manageable parts; (c) the synthesis which is used to put phenomena, processes from the divided parts into a more integral unity; (d) inductive reasoning " is the process of drawing reasonable general conclusions from specific facts or observations. In other words, it is a process going from the specific to the general. In induction, it is not possible to have logical certainty. There is always the chance that the next observation you make will disconfirm what all the previous observations have confirmed" (Sternberg \& Williams, 2010, p. 317); (e) deductive reasoning "is the process of drawing specific, logically valid conclusions from one or more general premises. In other words, it is a process of going from the general to the specific. By its nature, deductive reasoning leads to conclusions that are logically certain" (Sternberg \& Williams, 2010, p. 317). By using appropriate procedures, individuals can achieve systemic and creative thinking (Tetteh \& Sarpong, 2015; Zoller, 2015).

Economic sciences are the carriers of rational behaviour and thinking (Dasgupta \& David, 1994). The core of the approach to economic science was described by the American pragmatic philosopher Charles Sanders Peirce (1967) in his Note on the Theory of the Economy of Research. Peirce (1967) states that economic science uses an analytical apparatus derived from economic theory. This apparatus then uses methods of economic science and is applicable to other disciplines. Thus, economics offers a model of thinking that enriches the theory of science (Loužek, 2016, p. 496). Polanyi (1962, In Loužek, 2016, p. 496) points out that the community of scientists is able to solve riddles in a much easier way than an isolated person could be (The literal quote: "The community of scientists is able to solve riddles more easily than an isolated person would be. ") It works similarly in education, when teamwork reinforces students in both professional and soft skills.

The development of mainly higher cognitive dimensions is more effective with above average intelligent students who have better prerequisites and are oriented towards mastery goals. "Gifted students do not simply solve problems defined by others, but rather create new problems to solve and ask new types of questions" (Sternberg \& Williams, 2010, p. 167). Sternberg describes educational programmes for gifted students. For the above average students in the authors' sample, teachers can use namely the enrichment, which means invitations to more advanced levels of the topic or prepare activities that develop higher-level thinking skills and even research skills (e.g. a simple social research). The above-mentioned operations have also been tested in education using a based-learning model to help students develop models to support understanding of the subject matter. "The middle school students seemed to have a better understanding of scientific models than the high school students" (Cheng, Lin, Lin \& Cheng, 2017, p. 214). Assessing and enabling the critical and creative thinking of secondary school students is considered an important goal, and it is assumed that mainly students with above average intellectual level have considerable potential for application of high-level cognitive learning processes (Liu, He \& Li, 2015). As proven by various studies, several indicators belong among the most important ones to develop creativity: such as motivation (Liu, He \& Li, 2015), a balanced teaching style supporting the development of both hemispheres (Watkins \& Biggs, 2001), basic teaching aids, problem-solving method of teaching and applied scientific research (Subroto, 2015).

The term higher order cognitive skills (HOCS) is traditionally connected to the three highest levels of cognitive processes in the original Bloom's taxonomy (1956) - analysis, synthesis and evaluation (Crowe, Dirks \& Wenderoth, 2008). In the revised version of the taxonomy (Anderson \& Kratwohl, 2001), represented by a two-dimensional framework using six cognitive processes and four knowledge categories, synthesis is replaced by create in the cognitive process domain. Critical thinking and problem solving have not been included as major categories within the taxonomy. However, the authors maintain that both tend to involve cognitive processes in several categories across their cognitive process dimension. While Bloom
PROBLEMS

OF EDUCATION

IN THE $21^{\text {st }}$ CENTURY

Vol. 76, No. 2, 2018 
Kateřina BERKOVÁ, Kristýna KREJČOVÁ, Alena KRÁLOVÁ, Pavel KRPÁLEK, Katarína KRPÁLKOVÁ KRELOVÁ, Dana KOLÁŘOVÁ. The conceptual four-sector model of development of the cognitive process dimensions in abstract visual thinking

PROBLEMS

OF EDUCATION

IN THE $21^{\text {st }}$ CENTURY Vol. 76, No. 2, 2018

124

originally made implicit references to what researchers now call metacognition, Anderson and Kratwohl explicitly list metacognition as a type of knowledge. Bloom's taxonomy has proven to be a useful tool to conduct a deeper examination of the alignment of learning objectives, instruction and assessment that encourages educators to include more complex cognitive tasks in a classroom setting across all educational levels and disciplines. Regardless of new recognitions of the cognitive domains within RBT, the original Bloom's taxonomy is still recognized as an influential framework used for evaluating student performance on introductory exams (Bissel \& Lemons, 2006), developing formative assessment questions and assignments (Allen \& Tanner, 2002), guiding teaching strategies (Crowe, Dirks \& Wenderoth, 2008), scaffolding HOCS or promoting cognitive complexity in student written work (Granello, 2001). Although RBT lends itself to wide application, the researchers have not found any recent studies in which its practical utility as a tool for promoting HOCS has been formally assessed. The development of higher cognitive levels is reflected in the conceptual Higher-Order Cognitive Skills (HOCS) (Zoller, 2015), which represents the gnoseological process of systemic, evaluative, moral thinking and creativity development. For this purpose, several appropriate indicators experimentally verified in the secondary education are used: (a) problem solving; (b) transfer of experience, assumptions of students through experiential learning; (c) problem-solving questions (d) decision-making tasks with the support of moral, creative thinking and thinking skills assessment. The HOCS model is applicable to different levels of education.

The goal of education designed to help students become better thinkers is transferability to real-world, out-of-the-classroom situations (Newell \& Simon, 1972). There is a growing body of evidence that critical and creative thinking are applicable across a range of disciplinary areas and related skills are teachable and learnable. Instructional approaches to enhance HOCS involve case-based reasoning, problem-solving and inquiry-based learning activities that encourage students to formulate and test their ideas, draw conclusions and inferences, and pool and convey their knowledge in a collaborative learning environment (Barak, Ben-Chaim \& Zoller, 2007; Duch, Groh \& Allen, 2001; Nelson, 2008). Such approaches are attractive and motivating for students as well. An empirical study on the development of young people's systemic thinking and on the relation between cognition and motivation can serve as an evidence (Broks, 2016). Generally speaking cognition to develop intrinsic motivation is needed, that is to provide students with information that will raise their motivation. Therefore, it can be said that the relation between intrinsic motivation and cognitive processes is a two-way process, i.e. without intrinsic motivation, cognitive processes cannot be effectively developed, but intrinsic motivation is formed and raised by cognition.

In the context of this proposition the $E-R-R$ model of learning and thinking (Steel, Meredith, Temple \& Walter, 1997) mentioned in the Introduction, based on pedagogical constructivism is suitable for the accomplishment of the mentioned attributes. The model is oriented on what the learner should learn, and above all that the student himself should find out how they change their way of thinking and improve their ability to look at things from different points of view in order to gain life and expertise (Cubukcu, 2009; Tasci \& Yugurdi, 2017). It also contributes to the development of argumentation that is important for another way of thinking. Instructional methods based on argumentation support development of cognitive and metacognitive skills, skills of speaking and writing the language of science and habits of mind (e.g. questioning one's own beliefs, avoiding misinterpretation of reality for one's own needs, accurate reconstruction of someone else's ideas etc.) (Erduran \& Jiménez, 2008). Critical thinking of students improves faster when teaching is based on argumentation (Kirschner, Buckingham Shum \& Carr, 2002; Van Gelder, Bisset \& Cumming, 2004). Educators should model critical thinking in their own instruction by making their reasoning visible to students (Paul, 1992). 
Kateřina BERKOVÁ, Kristýna KREJČOVÁ, Alena KRÁLOVÁ, Pavel KRPÁLEK, Katarína KRPÁLKOVÁ KRELOVÁ, Dana KOLÁŘOVÁ. The conceptual four-sector model of development of the cognitive process dimensions in abstract visual thinking

\section{Problem of Research and Research Focus}

The research is focused on finding suitable cognitive approaches with analogies of methods of economic science for working with different groups of students in economic subjects in secondary education differentiated according to the intellectual level (average 90 - 109 IQ points and above average of 110 IQ points) and academic achievement related to real abilities and factors influencing students' motivation. This overview defines the theoretical basis for building a conceptual four-sector model of development of all dimensions of the cognitive process and its subsequent application to the process of learning in economic subjects in the context of abstract-visual thinking. The research has a character of pedagogical, empirical, applied research oriented to a certain degree of concreteness. In relation to the aim - to put together a conceptual model of the development of cognitive dimensions for students when studying an economic subject, the following hypotheses are being verified:

1. The academic achievement of students with an above average intellectual level in the level of abstract-visual thinking and with better school results in an economic subject depends on at least one of the teacher's competences studied.

2. The academic achievement of students with an above average intellectual level in the level of abstract-visual thinking and with worse school results in an economic subject depends on at least one of the teacher's competences studied.

3. The academic achievement of students with an average intellectual level in the level of abstract-visual thinking and with better school results in an economic subject depends on at least one of the teacher's competences studied.

4. The academic achievement of students with an average intellectual level in the level of abstract-visual thinking and with worse school results in an economic subject depends on at least one of the teacher's competences studied.

\section{Methodology of Research}

\section{General Background}

In the methodological level, research solution is based on the results of empirical research conducted in 2015 and 2016. The results of the research were published in three studies step by step. The first publication related to the influence of the studied factors (teacher's pedagogical competencies) on the motivation of students to study economic subjects using differentiation of students according to the above average and average intellectual level (Berková \& Krejčová, 2016). In the second publication, the application of metacognitive strategies in the teaching of economic subjects with the focus on methods of work with students with above average intellectual level was discussed (Berková, Králová \& Krejčová, 2017).

The third publication was focused on the causal relation between academic achievement and the real skills of the same structure of a year older students (as in the previous research) in economic studies (Berková \& Krpálek, 2017). The results are important for the creation of relevant synthesis based on these publications. Those students whose financial literacy skills were developed by different learning strategies were selected and as well gaining practical experience during their studies was considered. The age range was chosen to find out what the level of financial literacy among older students was in direct connection with economic disciplines, and whether learning outcomes were a strong factor determining their real cognitive economic skills. The researchers assessed the real level of students' economic skills according to partial dimensions of the cognitive process by testing. Achievement tests in two sets adapted to the age of students (17-18 years) according to the studied year and therefore according to the expected abilities correspond to the second category of measuring the level of financial literacy - the area of asset management and capital structure, cash flow management and finding ways to improve the financial situation of companies in the framework of the PISA 2012 survey (OECD, 
Kateřina BERKOVÁ, Kristýna KREJČOVÁ, Alena KRÁLOVÁ, Pavel KRPÁLEK, Katarína KRPÁLKOVÁ KRELOVÁ, Dana KOLÁŘOVÁ. The conceptual four-sector model of development of the cognitive process dimensions in abstract visual thinking

\section{PROBLEMS \\ OF EDUCATION \\ IN THE $21^{\text {st }}$ CENTURY Vol. 76, No. 2, 2018}

2014). The set of tests respected the revised Bloom Taxonomy in the first three levels, i.e. remembering, understanding, applying. The reason for implementing the partial representation of cognitive dimensions are mainly the results of the OECD (2014) survey of the insufficient ability of Czech students at that age to analyse difficult, not very obvious financial problems and situations in the long run. In the Czech Republic, more traditional approaches to teaching with a weak link to problem solving are still being used. Testing tasks also include situations in which students demonstrate the ability to use logical thinking and deeper thinking about contexts. Test tasks were therefore asked in a different way than it is typical for the teaching of economic subjects in Czech secondary education (i.e. memorization and encyclopaedism).

\section{Methodological Design}

Pedagogical competencies of the teacher were studied in five categories, which the researchers (Pasiar, Berková, Krejčová, Pavera, Čonková \& Chmelárová, 2015) consider to be key factors for the teaching of economic subjects in secondary education, each category comprising the following sets:

1. Communication skills (pronunciation, attraction, pace and melody, holding attention, paying attention, listening);

2. Presentation skills (examples real life situations, good actor, eye contact, managing of nervousness);

3. Explanation of the curriculum (practical relevance of the subject, acceptance of unusual ideas, explanation of mistakes);

4. Development of thinking (interest in the course of work, to lead to thinking);

5. Expertise (to respond to all inquiries in a correct and consistent manner).

The selection of these competences is supported by the research that has shown that poor learning outcomes are caused by Ranschburg effect in the range of $20-25 \%$ (Taylor \& Klein, 1998), which shows the poor rhetorical competencies of the teacher as a cause leading to deteriorating in student's academic achievement. It is therefore necessary for teachers to use the most varied range of language and various variations of terms (terminology). For this reason, the questioning how students assess their teachers of economic subjects in this respect was conducted. The visualization of the information is closely related to the mentioned language competence which means it is necessary for the teachers to change the diagrams, pictures, graphs, etc. The researchers try to prove whether the improvement of these competencies contributes to the improvement of academic achievement and to the increasing of motivational potential of the economic subject. The proof is that students with a lack of motivation and demotivated students are not interested in the process of solving tasks (i.e. a higher cognitive process) but are interested only in the outcome of the task as a finished product (Boekaerts, 2004). In order to achieve such a level of competency that would enhance the learning outcomes and increase the motivational potential of the subject, it is essential for the teachers at a higher level to have the ability to explain curriculum, develop and lead students to logical, abstract-visual thinking up to the level of economic thinking in the terms of economic education. In this respect, the teacher's expertise in the scientific discipline he teaches plays a significant role (Berková \& Krejčová, 2016).

\section{Sample}

The research sample was formed on the basis of intentional sampling, with the main selection criterion being a different methodological approach to the development of all cognitive process dimensions applied by teachers in the teaching of economic subjects in secondary education primarily focused on economics and accounting. The research carried out in 2015 (Berková \& Krejčová, 2016; Berková, Králová \& Krejčová, 2017), focusing on factors affecting academic achievement and motivation to study economic subjects, was participated 
Kateřina BERKOVÁ, Kristýna KREJČOVÁ, Alena KRÁLOVÁ, Pavel KRPÁLEK, Katarína KRPÁLKOVÁ KRELOVÁ, Dana KOLÁŘOVÁ. The conceptual four-sector model of development of the cognitive process dimensions in abstract visual thinking

in by 207 students aged 16-17, studying economic disciplines, (45\% of the sample was formed by individuals of 16 years of age and $56 \%$ by those of 17 years of age). At the level of abstractvisual thinking, 138 individuals (i.e. 49.8\%) are of above average intelligence (intellect level above 110 IQ points), 109 individuals (i.e. 39.4\%) are of average intelligence (intellect level range 90 - 109 IQ points) and 30 individuals (i.e. 10.8\%) are of below average intelligence (intellect level below 89 IQ points). Due to the very low number of bellow average intelligent individuals $(\mathrm{n}=30)$, this group is not analysed more closely. The sample is too small to be able to find out more suitable educational approaches to this group of students. For some individuals, with below average intelligence, the researchers assume that this is not a valid result due to the insufficient motivation. The analysis is therefore focused on the first two groups of students $n=$ 247 (Table 1). All respondents signed an informed consent form to participate in the research.

Table 1. Structure of respondents according to the intellectual level and academic achievement in the economic subject.

\begin{tabular}{lcccc}
\hline Grades & $\begin{array}{c}\text { Above Average Intelligent Students } \\
\text { Absolute } \\
\text { Frequency }\end{array}$ & $\begin{array}{c}\text { Relative Frequency } \\
\text { (in \%) }\end{array}$ & $\begin{array}{c}\text { Average Intelligent Students } \\
\text { Arequency }\end{array}$ & $\begin{array}{c}\text { Relative Frequency } \\
\text { (in \%) }\end{array}$ \\
\hline 1 - Excellent & 31 & 22.5 & 14 & 12.8 \\
\hline 2- Very Good & 51 & 37.0 & 32 & 29.4 \\
\hline 3- Good & 40 & 29.0 & 45 & 41.3 \\
\hline $4-$ Sufficient & 10 & 7.2 & 18 & 16.5 \\
\hline $5-$ Insufficient & 6 & 4.3 & 0 & 0 \\
\hline Total & 138 & 100 & 109 & 100 \\
\hline
\end{tabular}

The research sample is further monitored according to school grades within groups of students with above average and average intellectual levels. To build a conceptual foursector model, academic achievement is synthesized into two groups: (a) better achievement at school from the grade point of view 1-Excellent; 2-Very Good, in which 82 (i.e. 59.5\%) students are with an above average intellectual level and 46 (i.e. 42.2\%) students are with an average intellectual level; (b) worse achievement at school from the grade point of view 3-Good; 4-Sufficient; 5-Insufficient, where 56 (i.e. 41.5\%) are students with above average intellectual level and 63 (i.e. 57.8\%) are students with an average intellectual level.

\section{Research Instrument}

In order to measure the influence of the studied factors - pedagogical competencies of teachers of economic subjects in secondary education - on the academic achievement and motivation of students in economic subjects, two research methods were used - (a) the questioning method, (b) testing in association with the diagnostic Testcentrum in the Czech Republic. The research tools for this measurement were a non-standardized questionnaire designed for the purpose of solving applied research with a certain degree of concreteness and a Vienna paper-pencil version test (Forman, 2002). The test allows to quantify the general level of intellectual performance in the level of abstract-visual thinking. The test itself takes a maximum of 25 minutes. "The test consists of 24 items, which are organised with increasing difficulty. Each task contains a $3 \times 3$ image matrix with the missing picture in the third row. The task is to complement the matrix by selecting one of the eight solutions offered. The core of the solution is to discover a rule that determines the relation between the images in each row
PROBLEMS

OF EDUCATION

IN THE $21^{\text {st }}$ CENTURY

Vol. 76, No. 2, 2018 
Kateřina BERKOVÁ, Kristýna KREJČOVÁ, Alena KRÁLOVÁ, Pavel KRPÁLEK, Katarína KRPÁLKOVÁ KRELOVÁ, Dana KOLÁŘOVÁ. The conceptual four-sector model of development of the cognitive process dimensions in abstract visual thinking

\section{PROBLEMS \\ OF EDUCATION \\ IN THE $21^{\text {st }}$ CENTURY \\ Vol. 76, No. 2, 2018}

or column. The test contains several types of rules that need to be applied correctly. Creating a rule consists of revealing and understanding the interrelation between the elements, finding and deriving the relevant solution. The overall strategy uses perception, thinking, attention, and working memory " (Forman, 2002, p. 8).

On the basis of analytical approach, the purpose of questioning was to find out how these students evaluate selected teachers' pedagogical competences in the teaching of economic subjects. The questionnaire was structured into the following sections: (a) student data (gender, secondary school, student identification number, grade from the subject of Economics); (b) weekly student preparation time (identified by the codes on scales 1 - 5 representing the following time intervals) - I do not prepare for the subject at all (1), less than 60 minutes (2), 1-2 hours (3), 2 - 4 hours (4), more than 4 hours (5); (c) evaluation of the teacher's pedagogical competencies.

\section{Data Analysis}

The data were analysed using the NCSS statistical program (version 2007). Verification of null hypotheses was performed at a significance level of 5\% using a multiple regression model via the t-parameter test and the F-test model.

When hypothesis is verified by a mathematical-statistical apparatus, the null hypothesis asserts that there is no dependence between the variables. Null hypotheses and alternative hypotheses are formulated as follows:

$H_{0-1}: \beta_{i}=0$

Academic achievement of students with an above average intellectual level in the level of abstract-visual thinking and with better school results in an economic subject does not depend on any of the teachers' competencies studied.

$$
H_{1-1}: \text { non } H_{0-1}
$$

$\mathrm{H}_{0-2}: \beta_{i}=0$

Academic achievement of students with an above average intellectual level in the level of abstract-visual thinking and with worse school results in an economic subject does not depend on any of the teacher's competencies studied.

$H_{1-2}:$ non $H_{0-2}$

$H_{0-3}: \beta_{i}=0$

Academic achievement of students with an average intellectual level in the level of abstract-visual thinking and with better school results in an economic subject does not depend on any of the teacher's competences studied.

$$
H_{1-3} \text { : } \text { non } H_{0-3}
$$

$H_{0-4}: \beta_{i}=0$

Academic achievement of students with an average intellectual level in the level of abstract-visual thinking and with worse school results in an economic subject does not depend on any of the teacher's competences studied.

$$
H_{1-4}: \text { non } H_{0-4}
$$

For $n=247$ the normality of quantitative data was determined by the KolmogorovSmirnov test. The reliability of the test is increased by the number of measurements $(n>100)$. The data layout was verified by exploration analysis. Thus, the dependency of the explained variable $y$ (grades) on the seven explanatory variables $x_{1}, x_{2}, x_{3}, x_{4}, x_{5}, x_{6}, x_{7}$ is quantified, while $x_{1}$ representing the intellect level, $x_{2}$ weekly preparation, $x_{3}$ communication, $x_{4}$ presentation, $x_{5}$ explanation of the curriculum, $x_{6}$ development of thinking, $x_{7}$ expertise. Selective partial regression coefficients are an estimate of the theoretical regression coefficients that can 
Kateřina BERKOVÁ, Kristýna KREJČOVÁ, Alena KRÁLOVÁ, Pavel KRPÁLEK, Katarína KRPÁLKOVÁ KRELOVÁ, Dana KOLÁŘOVÁ. The conceptual four-sector model of development of the cognitive process dimensions in abstract visual thinking

\begin{tabular}{|l} 
PROBLEMS \\
OF EDUCATION \\
IN THE 21 $1^{\text {st }}$ CENTURY \\
Vol. 76, No. 2, 2018 \\
\hline 129
\end{tabular}

be obtained by the least squares method. The regression coefficients $b_{0}$ and $b_{i}$ quantify the influence of each independent variable on the dependent variable. This determines the largest and smallest influence of independent variables on the dependent variable, and also if they are in a positive (+) or negative (-) relation. Variables included in the multiple regression model must be as minimally dependent on each other as possible (Draper \& Smith, 1998). Therefore, method Stepwise is used to determine the multi-collinearity. Furthermore, the magnitude of the correlation coefficient $R^{2}$, which shows the dependence strength, will be monitored. Explanatory variables must have a linear dependence that can be measured by a Spearmen correlation coefficient the value of which should be higher than 4 .

For the 247 students monitored in 4 groups according to the intellectual level and the academic achievement, an estimate of empirical function with these parameters was carried out. Mathematically, the linear regression model can be represented by a formula (Draper \& Smith, 1998):

$$
\begin{gathered}
Y=f\left(x ; b_{0}, b_{1}, b_{2}, b_{3}, b_{4}, b_{5}, b_{6}, b_{7}\right), \\
Y=f\left(x ; b_{0}, b_{1}\right),
\end{gathered}
$$

where: $b_{0}$ - constant, $b_{1}-b_{7}$ - values of empirical function (estimates of theoretical regression function).

The estimation of the regression function for $\mathrm{n}=247$ can be written in the form:

$$
Y=b_{0}+b_{T} x_{i}+\ldots+b_{7} x_{i}
$$

provided the conditions of the multiple regression model are met.

\section{Results of Research}

Based on the result of the normality test (for $n=247, p=.053$ ) and exploration analysis, the data were transformed and after the transformation there was not any significant improvement.

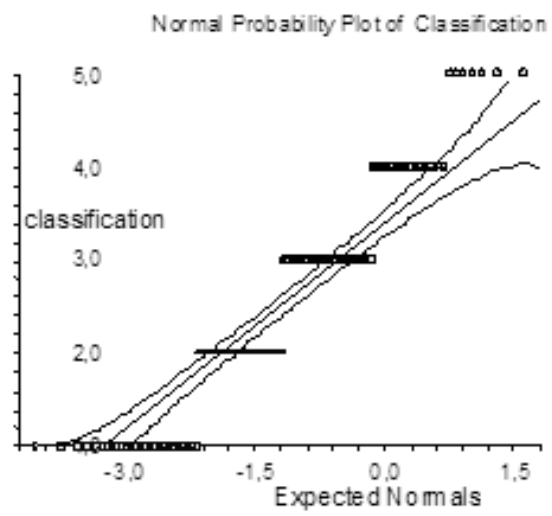

Figure 1: Exploratory analysis.

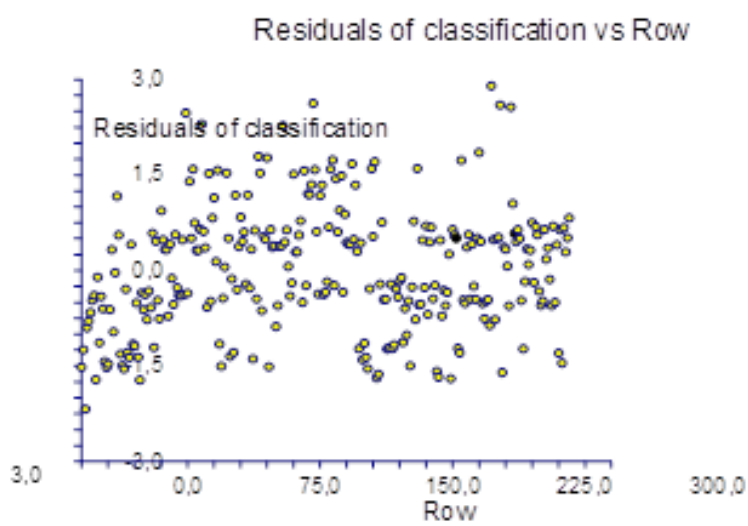

Figure 2: Residue analysis.

Despite the above results, the model residues are approximately constantly scattered around the zero mean value, which means they have no tendency and the model can be considered correct (Figure 1-2). With respect to the boundary result of normality testing, default data were used for further quantitative analysis. 
Kateřina BERKOVÁ, Kristýna KREJČOVÁ, Alena KRÁLOVÁ, Pavel KRPÁLEK, Katarína KRPÁLKOVÁ KRELOVÁ, Dana KOLÁŘOVÁ. The conceptual four-sector model of development of the cognitive process dimensions in abstract visual thinking

PROBLEMS

OF EDUCATION

IN THE $21^{\text {st }}$ CENTURY

Vol. 76, No. 2, 2018

130

\section{Scientific Evidence for Building a Conceptual Model of Development of Cognitive Process Dimensions}

To verify null hypotheses, the multicollinearity between the explanatory variables $x_{1}-x_{7}$ was assessed using the Spearman correlation coefficient with the use of correlation matrix.

The original results of the research are monitored according to the intellectual level of students. For a group of students with an above-average intellectual level, the variables examined were broadened compared to the original survey in 2017. This is a modified research. For this group of students level $(\mathrm{n}=138)$ the following results were found: (a) communication skills strongly correlate with other explanatory variables (correlation coefficient was higher than .4); (b) presentation skills correlate with other explanatory variables (correlation coefficient was higher than .4), at the same time the strongest correlation between communication and presentation skills was found (.856); (c) explaining the curriculum and developing thinking skills are also in a strong correlation relation; (d) the expertise has a correlation relation that is the least strong and the correlation coefficient is in the range of .687-.544. At the same time the significance of the correlation relation for all combinations of linear dependence of the explanatory variables on the significance level of $5 \%(\mathrm{p}<.01)$ was confirmed.

For a group of students with an average intellectual level $(n=109)$, almost identical results as in the previous group were found. The significance of the correlation relation for all combinations of linear dependence of the explanatory variables on the $5 \%$ significance level ( $\mathrm{p}$ $<.01)$ was confirmed as well.

For students with higher and lower academic achievement within the main two groups according to the intellect level, similar Spearmen correlation coefficients were also found and a correlation between explanatory variables $(\mathrm{p}<.01)$ was established at the $5 \%$ significance level.

Multiple linear regression analysis was quantified by the linear dependence of academic achievement of above average and average intelligent students with better and worse school results on the factors examined. Estimates of partial regression coefficients $b i$ and regression analysis results by the Stepwise method are given in Tables 2 and 3.

Table 2. Multiple regression analysis model - students with an above average intellectual level $(n=138)$.

\begin{tabular}{llllll}
\hline & $\begin{array}{l}\text { Regression } \\
\text { Coefficient } b_{i}\end{array}$ & $\begin{array}{l}\text { Standard Error } \\
S b_{i}\end{array}$ & $\begin{array}{l}\text { T-Value to test } \\
\mathrm{H}_{0}: \mathrm{B}(\mathrm{i})=0\end{array}$ & $\mathrm{p}$ & $\begin{array}{l}\text { Reject } \mathrm{H}_{0} \\
\text { at 5 \% }\end{array}$ \\
\hline Intercept & 2.8924 & 1.6297 & 1.775 & .0783 & No \\
\hline $\mathrm{IQ}$ & .0234 & .0137 & -.296 & .7675 & No \\
\hline Time & -.0041 & .1027 & .228 & .8199 & No \\
\hline Communication & -1.2137 & .9484 & -1.280 & .2029 & No \\
\hline Presentation & .3729 & .8118 & .459 & .6468 & No \\
\hline Explanation & -.2465 & .6040 & -.408 & .6839 & No \\
\hline Development of thinking & -.3608 & .6320 & -.571 & .5691 & No \\
\hline Expertise & 1.0942 & .4888 & 2.239 & .0269 & Yes \\
\hline
\end{tabular}

The teacher's expertise influences the improvement of the academic achievement of a group of students with above average intellectual level, regardless of the academic achievement $(\mathrm{p}=.0269)$. At the same time, with $95 \%$ confidence interval within a group of test-takers, it is applied that if the teacher's qualification of the subject of Economics increases by 1 grade, the academic achievement of students with an above average intellectual level improves by 1.094 (by 1 school grade). At the same time, at the risk of $5 \%$, it can be stated that the academic achievement of these students is not dependent on the other variables. Less variability is 
Kateřina BERKOVÁ, Kristýna KREJČOVÁ, Alena KRÁLOVÁ, Pavel KRPÁLEK, Katarína KRPÁLKOVÁ KRELOVÁ, Dana KOLÁŘOVÁ. The conceptual four-sector model of development of the cognitive process dimensions in abstract visual thinking

explained in the model. The value of $\mathrm{R}^{2}$ is .0506 . This means that other variables which have not been included in the model influence the academic achievement as well.

The average academic achievement of a group of students with an above average intellectual level, regardless of academic achievement and the influence of independent variables, reaches 2.89 . This value does not correspond to the above average intellectual level of students, which is caused by the representation of 56 individuals $(40.5 \%)$ with grade $3,4,5$ where the average teacher' s assessment is 3.39 . There are only $59.5 \%$ of the students who get grades 1 and 2 with an average grade of 2.11 .

With $95 \%$ confidence in the test, the researchers reject $\mathrm{H}_{0-1}$. It can be stated that there is a positive dependence on the academic achievement of students with above average intellectual level and with better school results in the subject of Economics on the teacher's expertise ( $p$ $<.01$ ), so increasing the teacher's qualification will increase the academic achievement of these students, but at a slower pace.

The regression model of multiple dependence for $\mathrm{n}=82$ can be described as follows:

$Y_{\mathrm{i}}=2.1058+.772 x_{7 i}$

If the teacher's qualification is increased by 1 grade, academic achievement of students with above average intellectual level and better school results will be improved by .772 (less than 1 school grade). Without the influence of independent variables, successful students will achieve worse results at school, on average 2.11, than in case of the influence of variables (average score with the influence of variables at $\mathrm{p}<.01$ is 1.62 ).

Although for the whole group of students with above average intellectual level, regardless of academic achievement, the significant factor for improving academic achievement (grades) is the teacher's expertise, but this relation does not apply to a group of students with worse results (for $\mathrm{n}=56$ applies $\mathrm{p}>$.05). The researchers do not reject $\mathrm{H}_{0-2}$ with $95 \%$ confidence interval. It can be stated that there is no dependence on the academic achievement of students with above average intellectual level and with worse school results in the subject of Economics of at least one of the variables examined. For students with an average teacher' s assessment of 3.39, their academic achievement, without the influence of independent variables, improves to 1.17 on average.

Table 3. Multiple regression analysis model - students with an average intellectual level $(\mathbf{n}=\mathbf{1 0 9})$.

\begin{tabular}{llllll}
\hline & $\begin{array}{l}\text { Regression } \\
\text { Coefficient } b_{i}\end{array}$ & $\begin{array}{l}\text { Standard } \\
\text { Error } \\
S^{\prime}\end{array}$ & $\begin{array}{l}\text { T-Value to test } \\
\mathbf{H}_{0}: \mathrm{B}(\mathrm{i})=\mathbf{0}\end{array}$ & $\mathrm{p}$ & $\begin{array}{l}\text { Reject } \mathrm{H}_{0} \\
\text { at 5\% }\end{array}$ \\
\hline Intercept & 3.3426 & 1.9500 & 1.714 & .0896 & No \\
\hline $\mathrm{IQ}$ & -.0062 & .0186 & -.334 & .7390 & No \\
\hline Time & -.0671 & .1079 & -.622 & .5351 & No \\
\hline Communication & -2.0321 & .7356 & -2.762 & .0068 & Yes \\
\hline Presentation & 1.6622 & .7770 & 2.139 & .0348 & Yes \\
\hline Explanation & .0719 & .6630 & .108 & .9139 & No \\
\hline Development of thinking & .2563 & .5304 & .483 & .6300 & No \\
\hline Expertise & -.0786 & .4481 & -.175 & .8611 & No \\
\hline
\end{tabular}

To improve the academic achievement of a group of students with an average intellectual level, regardless of academic achievement, the teacher's communication skills $(p=.0068)$ and the presentation skills $(\mathrm{p}=.0348)$ have effect. At the same time, with $95 \%$ confidence interval within the group of test-takers, it is applied that if the presentation skills of the teacher in the subject of Economics are improved by 1 grade, the academic achievement of students with an 
Kateřina BERKOVÁ, Kristýna KREJČOVÁ, Alena KRÁLOVÁ, Pavel KRPÁLEK, Katarína KRPÁLKOVÁ KRELOVÁ, Dana KOLÁŘOVÁ. The conceptual four-sector model of development of the cognitive process dimensions in abstract visual thinking

PROBLEMS

OF EDUCATION

IN THE $21^{\text {st }}$ CENTURY Vol. 76, No. 2, 2018

132

average intellect level will be improved on average by 1.662 (almost by 2 school grades) and at the same time if the communication skills of a teacher in the subject of Economics get worse by 1 degree, the academic achievement will improve by an average intellectual level of 2.032 on average (by 2 school grades). At the same time, at the risk of 5\%, it can be stated that the academic achievement of these students is not dependent on the other variables. Less variability is explained in the model. The value of $\mathrm{R}^{2}$ is .0829. This means that other variables which have not been included in the model influence the academic achievement as well.

The average school achievement of a group of students with an average intellectual level regardless of academic achievement and without the influence of independent variables reaches 3.34. This value corresponds to the student's intellectual level. In the monitored group there are $57.8 \%$ of students with worse grades (grades 3 and 4 ) where the average assessment by the teacher was 3.29. The remaining $42.2 \%$ of individuals surveyed are assessed at grade 1 and 2 and their average teacher's assessment is 1.70 . With $95 \%$ confidence interval, the researchers reject $\mathrm{H}_{0-3}$. It can be stated that there is a positive dependence on the academic achievement of students with an average intellectual level and better school results in the subject of Economics on the communication and presentation skills of the teacher $(\mathrm{p}<.01)$.

The regression model of multiple dependence for $\mathrm{n}=46$ can be described as follows:

$$
Y_{\mathrm{i}}=4.0317+1.102 x_{3 i}+2.016 x_{4 i}
$$

If the communication skills of the teacher in the subject of Economics improve by 1 grade, the achievement rate of the students will be improved by an average of 1.102 (by 1 grade) and at the same time improving the presentation skills of the teacher in the subject of Economics by 1 grade, students' academic achievement will be better on average of 2.016 (by 2 grades). Without the impact of independent variables, students will achieve worse results at school namely 4.03 on average than with the impact of variables (average scores with variables at $\mathrm{p}<.01$ reaching 1.70 ).

Although for the whole group of students with an average intellectual level, regardless of academic achievement, the teacher's communication and presentation skills are significant for improving the school results, but this relation does not apply to a group of students with worse results (for $n=63$ applies $\mathrm{p}>.05$ ). The researchers do not reject $\mathrm{H}_{0-4}$ with $95 \%$ confidence interval. It can be stated that there is no dependence on the academic achievement of students with an average intellectual level and with worse academic achievement in the subject of Economics for at least one of the variables examined. Students with an average teacher's assessment of 3.29 will reach slightly worse assessment at an average of 3.35 without the influence of the variables.

The effects of the variables on the change of academic achievement for each student group (sector) are shown in Table 4, which describes the average values of the school assessment without the influence and with the influence of variables and the average value of the intellectual level for each sector. The results show that, with the exception of the second sector, teacher's involvement is important to improve students' academic achievement.

Table 4. Description of sectors in terms of the impact of variables on academic achievement.

\begin{tabular}{llll}
\hline Sectors (Student Groups) & $\begin{array}{l}\text { Average Value of } \\
\text { the Intellect Level }\end{array}$ & $\begin{array}{l}\text { Average Grade with- } \\
\text { out the Influence of } \\
\text { Variables }\end{array}$ & $\begin{array}{l}\text { Average Grade with } \\
\text { the Influence of Vari- } \\
\text { ables }\end{array}$ \\
\hline $\begin{array}{l}\text { Students with above average intellec- } \\
\text { tual level and better study results }\end{array}$ & 118.59 & 2.11 & 1.62 \\
\hline $\begin{array}{l}\text { Students with above average intellec- } \\
\text { tual level and worse study results }\end{array}$ & 117.63 & 1.17 & 3.39 \\
\hline $\begin{array}{l}\text { Students with an average intellectual } \\
\text { level and better study results }\end{array}$ & 100.07 & 4.03 & 1.70 \\
\hline $\begin{array}{l}\text { Students with an average intellectual } \\
\text { level and worse study results }\end{array}$ & 100.27 & 3.35 & 3.29 \\
\hline
\end{tabular}


Kateřina BERKOVÁ, Kristýna KREJČOVÁ, Alena KRÁLOVÁ, Pavel KRPÁLEK, Katarína KRPÁLKOVÁ KRELOVÁ, Dana KOLÁŘOVÁ. The conceptual four-sector model of development of the cognitive process dimensions in abstract visual thinking

\section{Conceptual Four-Sector Model of the Development of Cognitive Process Dimensions}

The cognitive approach used to teach an economic subject influences several important aspects that need to be worked out effectively in teaching so that each group of students can develop the skills that are realistically possible to be developed. The conceptual model (Figure 3 ) is developed into four sectors, depending on the intellectual level in the level of abstractvisual thinking and the academic achievement of the monitored students $(n=247)$.

For each sector it is suggested which dimensions of the cognitive process can be developed in the economic subject of one or the same group of students in terms of cognitive levels $R=$ Remember; $U=$ Understand; $A=$ Apply; $A=$ Analyse; $E=$ Evaluate $C=$ Create according to the revised Bloom Taxonomy. Each sector reflects the motivation for a given group of students. (The arrows shown in the model indicate the power of motivation, each group of students has a different intrinsic motivation - its strength is shown by the number of arrows, so the logic of the model is that the less arrows in the students' intrinsic motivation, the more motivating the teacher should be.)

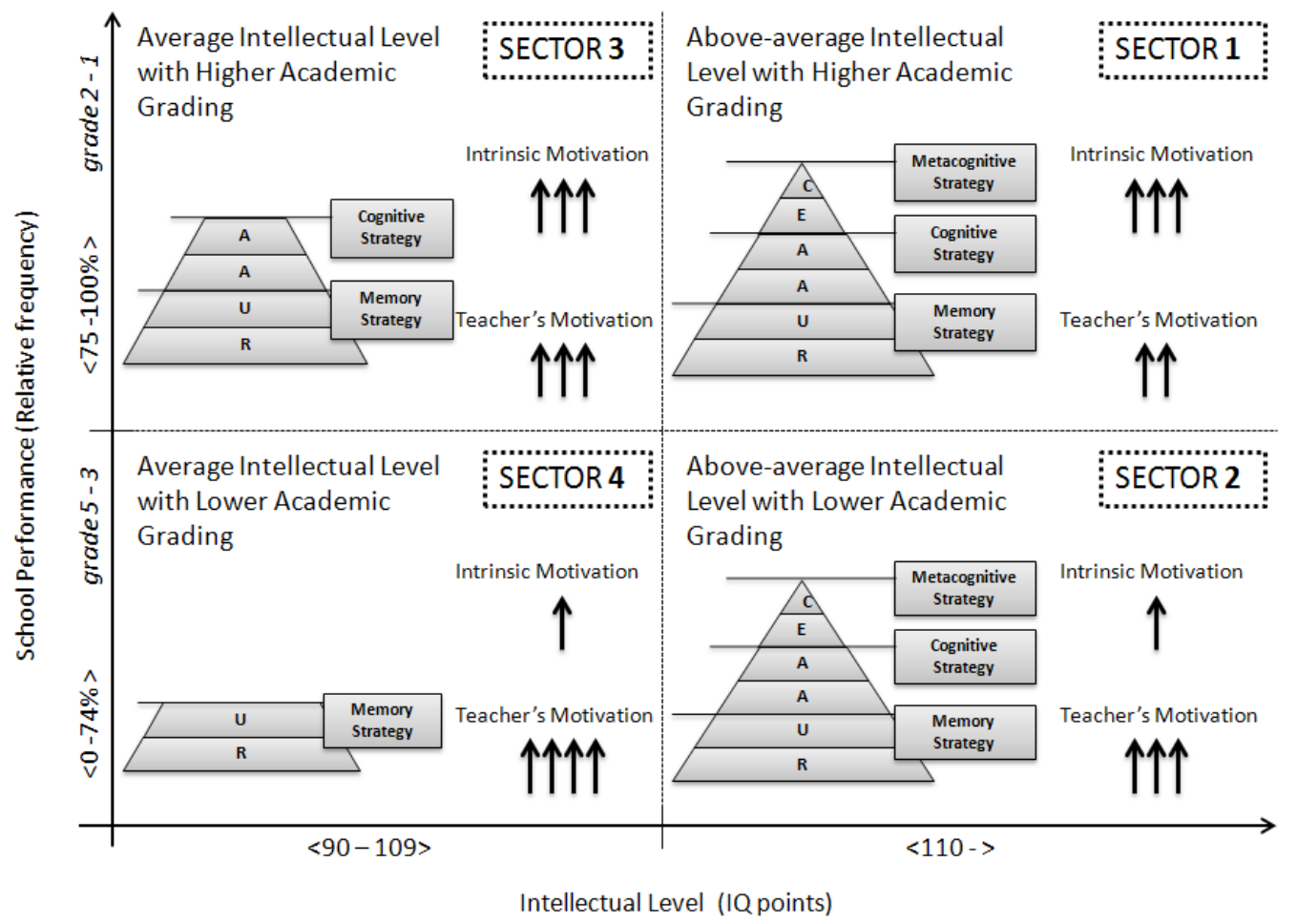

\section{Figure 3: A conceptual four-sector model of the development of cognitive process dimensions.}

From the monitored pedagogical competencies of the teachers, the significant motivating factor of students with an above average intellectual level is their expertise. Although the ability to explain the curriculum did not reach significant values, it is worth noting that this result was very tight. For average intelligent students, it is the teacher's expertise. For other pedagogical competencies (communication and presentation skills and development of thinking), motivation potential was not identified at a significance level of 5\%. Furthermore, it was found that students assessed by higher grades (grade 1-excellent, 2-very good) are more enthusiastic and have higher intrinsic motivation. Thus, the teacher would no longer have to develop such a strong motivational effect, as this group of students is self-driven for the studies. In the case of 
Kateřina BERKOVÁ, Kristýna KREJČOVÁ, Alena KRÁLOVÁ, Pavel KRPÁLEK, Katarína KRPÁLKOVÁ KRELOVÁ, Dana KOLÁŘOVÁ. The conceptual four-sector model of development of the cognitive process dimensions in abstract visual thinking

OF EDUCATION

IN THE $21^{\text {st }}$ CENTURY Vol. 76, No. 2, 2018

134

students assessed by lower grades, this relation is the opposite, so the teacher should be able to apply different teaching methods to keep this group of students constantly active in the teaching process.

\section{Discussion}

Generally, relations captured within the conceptual four-sectoral model of cognitive dimension development with an emphasis on students' motivation can be explained by the following causality, based on the results of the empirical research and generally accepted knowledge (Barrett \& Moore, 2012; Liu, He \& Li, 2015; Savin-Baden, 2004; Subroto, 2015; Watkins \& Biggs, 2001): Teacher's competence significantly influences the student's motivation for the given economic subject, and since the expertise is in correlation with the other teacher's competences (see correlation coefficient values) then motivation is influenced by other monitored competencies (to explain curriculum, development of thinking, communication and presentation skills). This is consistent with the research (Al-Baddareen, Ghaith \& Akour, 2015), which has shown that students with a deeper understanding of information have higher academic motivation than those who have a good test performance. A target orientation categorized into: (a) mastery goals; (b) performance goals and their impact on academic achievement plays a role as well. Gul \& Shehzad, (2012) have empirically proved that targeting goals on solutions, challenges, or just getting good grades does not affect academic achievement. The poor relation between academic achievement and target orientation may be due to a discrepancy between the ways of thinking and the goals to which students are led and their ways of thinking and the goals they want to achieve themselves. This is why motivation is very important, it stimulates the development of creativity ( $\mathrm{Liu}, \mathrm{He} \& \mathrm{Li}, 2015$ ), as well as a balanced teaching style supporting the development of both hemispheres (Subroto, 2015) and problem-solving teaching (Subroto, 2015; Zoller, 2015). Nevertheless, the authors' research (Gul \& Shehzad, 2012) was not made in terms of the differentiation of students according to the intellectual level in the level of abstractvisual thinking, so it was not possible to identify concrete educational needs and possible causes of good or bad results at school according to students' skills needed for studying. However, the results of the research have shown that the development of creativity can be achieved by students with an above average intellectual level.

According to the results of the research, the increasing motivational effect of the teacher can also be reflected in the improvement of the students' academic achievement in the way that teacher catches student's attention by what he explains because it leads to a deeper understanding of the situation and leads to solving problems for which the student must use higher cognitive processes - inductive thinking, deduction, analysis, synthesis, abstraction (Sternberg \& Williams, 2010 compare with methods of economic science according to the scientific approach of Peirce (1967); Jurečka, 2003). This results in the natural development of real abilities of students applied in economic issues and the creation of professional insight. This is in line with the research again (Gul \& Shehzad, 2012), stating that mastery goal-oriented students have more developed metacognitive strategies that allow them to penetrate deeper into information, which increases their academic motivation. It is also in line with pedagogical constructivism, for example in the form of the $E-R-R$ model (Cubukcu, 2009; Steel, Meredith, Temple \& Walter, 1997; Tasci \& Yugurdi, 2017) which is oriented on the way students find out themselves how they change their way of thinking and how they improve their ability to look at things from different angles. This model contributes to the development of critical thinking as well (Erduran \& Jiménez, 2008).

However, for each group of students in the research sample, other factors influencing the academic achievement and increasing motivation apply.

Sector 1 includes students with an above average intellectual level of more than 110 IQ points and who are successful in the economic subject in terms of school requirements (1-excellent, 2-very good). This group of students perceives the teacher as a lower level expert 
Kateřina BERKOVÁ, Kristýna KREJČOVÁ, Alena KRÁLOVÁ, Pavel KRPÁLEK, Katarína KRPÁLKOVÁ KRELOVÁ, Dana KOLÁŘOVÁ. The conceptual four-sector model of development of the cognitive process dimensions in abstract visual thinking

and requires a deeper understanding of economic issues (focus on mastery goals). Therefore, it is possible to develop all dimensions of the cognitive process with these students (see Figure 3), through inductive thinking, deduction, analysis, synthesis, abstraction (Sternberg \& Williams, 2010, see methods of economic science according to Peirce's scientific approach Peirce (1967); Jurečka (2003). Development is therefore possible with the help of problem solving and the same indicators as presented in the conceptual model HOCS (Zoller, 2015). Suggested cognitive approaches can be considered as justified thanks to the high intrinsic motivation of these students. Proof of this statement is the research (Broks, 2016), which has demonstrated the relation between intrinsic motivation and cognition: without intrinsic motivation, cognitive processes cannot be efficiently developed, but intrinsic motivation is created and increased through cognition. However, even with these students, there is a risk of deepening their lack of interest because they require deeper knowledge that they lack (due to the prevailing memorizing and encyclopaedism). It is therefore necessary to provide students with information that will raise their motivation, even though their intrinsic motivation is already high, which is proved by good academic achievement, but on the other hand desired goals of students are not being fulfilled and students are not guided to the desired way of thinking This phenomenon is proved by the results of research in Table 5 (Berková \& Krpálek, 2017). The power of the causal relationship between achievement and real abilities is considered. The academic achievement and real abilities of the students were measured by gaining points. To be able to compare the abilities gained points were transformed into a relative form.

Table 5. Academic achievement results (academic grading) versus the actual performance in the individual cognitive dimension.

\begin{tabular}{llllll}
\hline $\begin{array}{l}\text { Academic grading in } \\
\text { the given subject }\end{array}$ & $\begin{array}{l}\text { Performance } \\
\text { in the dimen- } \\
\text { sion- } \\
\text { Remember }\end{array}$ & $\begin{array}{l}\text { Performance } \\
\text { in the dimen- } \\
\text { sion - } \\
\text { Understand }\end{array}$ & $\begin{array}{l}\text { Performance } \\
\text { in the dimen- } \\
\text { sion - } \\
\text { Apply }\end{array}$ & $\begin{array}{l}\text { Performance } \\
\text { in all dimen- } \\
\text { sions }\end{array}$ & $\begin{array}{l}\text { Academic grad- } \\
\text { ing reflecting the } \\
\text { actual skill }\end{array}$ \\
\hline $1<1-0.9>$ & .565 & .692 & .408 & .555 & 4 \\
\hline $2<.89-.75>$ & .522 & .618 & .280 & .473 & 5 \\
\hline $3<.74-.6>$ & .532 & .577 & .242 & .450 & 5 \\
\hline $4<.59-.5>$ & .455 & .509 & .202 & .389 & 5 \\
\hline $5<.49-0>$ & .481 & .513 & .141 & .378 & 5 \\
\hline
\end{tabular}

Sector 2 includes students with an above average intellectual level of more than 110 IQ points and those who are not at the same time successful in the economic subject (their assessment is 3 - good, 4 - sufficient, 5 - insufficient). Working with this group of students, teaching management will always be more demanding compared to sector 1 . This can be explained by the fact that these students perceive the teacher as a lower level professional and therefore require deeper knowledge (as in sector 1). However, their lack of interest in their studies can be considered as a major cause of their poor performance mainly caused by applied cognitive methods focused on memorizing and encyclopaedism. These students demand a different way of thinking and other goals (mastery goals) that they do not get, and these goals are not being fulfilled. This is confirmed by the authors' research (Watkins \& Biggs, 2001), when students do not experience fulfilling of desired goals because they lack the right teaching style supporting the development of both hemispheres. Students are then in opposition to the teacher and studies, which demonstrates a considerable deterioration in the grades provided that the teacher as a personality has influence on them (see Table 4, Watkins \& Biggs, 2001). Their intrinsic motivation is significantly weak. This also proves the causal relation between real ability and achievement of students, when students with worse school results were able to 
Kateřina BERKOVÁ, Kristýna KREJČOVÁ, Alena KRÁLOVÁ, Pavel KRPÁLEK, Katarína KRPÁLKOVÁ KRELOVÁ, Dana KOLÁŘOVÁ. The conceptual four-sector model of development of the cognitive process dimensions in abstract visual thinking

PROBLEMS

OF EDUCATION

IN THE $21^{\text {st }}$ CENTURY Vol. 76, No. 2, 2018

136 at school (Berková \& Krpálek, 2017). Although, according to the results, teachers' performance will influence academic achievement in a negative way, research suggests (Broks, 2016) that intrinsic motivation can be formed. Then, it can be stated that it is possible to develop higher cognitive levels for these students (Anderson \& Kratwohl, 2001; Bissel \& Lemons, 2006; Crowe, Dirks \& Wenderoth, 2008) (see Figure 3) and present information in the way they require to meet their educational needs. With regard to the considerable opposition of this group of students, it can be expected that the implementation process of these methods will be difficult.

Sector 3 represents a group of students with an average intellectual level ranging from 90 to 109 IQ points and a higher achievement rate (rated 1-excellent, 2-very good). The teacher is perceived as a higher level expert compared to above average intelligent students. This is given by the level of intellect that does not allow students, even with higher academic achievement, to gain knowledge as deeply as students in sectors 1 and 2 . This proves a causal relation between real abilities and the students' academic achievement showing that students with excellent school results were unable to solve more challenging tasks concerning logical reasoning than students with worse school results (see Table 5 and also Table 4). These students are focused on good grades and performance in tests (performance goals) (Gul \& Shehzad, 2012). Therefore, all these cognitive levels cannot be developed with these students, but it is only possible to get to the fourth level analysis through cognitive learning strategies (see Figure 3) with the help of inductive thinking or abstraction, which allow the object of the research to make the analysis available. From the HCOS model (Zoller, 2015), problem-solving, transfer, problem questions can be used to work with this group, or the indicators that support creative or systematic thinking are not possible to be applied. The intrinsic motivation of these students does not place such high demands on teachers as for example students in sector 2. Students in sector 3 are sensitive to the communication and presentation skills of the teacher, which significantly improve academic achievement in terms of drawing and holding the teacher's attention, using variations of formulations, way of interesting presentation of curriculum with the ability to be a good actor and use of examples from real life. The researchers believe that this group of students is still interested in studying, so it is necessary to choose an active approach and strive for the development of higher cognitive levels. (Proof is the average score with the influence of the variables that makes 1.70 and without the influence of significant teacher competencies, which diametrically grows to a critical value of 4.03 .)

Sector 4 is represented by a group of students with an average intellectual level ranging from 90 to 109 IQ points, and with a lower achievement rate (3-good, 4-sufficient). As well as students in sector 3, this group perceives a higher-level of teacher's expertise. This relation is again conditioned by a lower intellectual level that does not allow students to achieve higher cognitive levels. School requirements at the lowest levels are demanding for them anyway. (Proof of the school's evaluation of this group - without the influence of variables it is 3.35 and with the influence of the variables there is a slight decrease to 3.29.) For these students it is appropriate to apply memory strategies of learning with a focus on the level of memorization and understanding of the main knowledge, i.e. it is necessary to focus on performance goals (Gul \& Shehzad, 2012). To improve the achievement of these students, the teachers' competencies examined do not have a significant impact. However, due to the intellectual level of these students and their lack of interest in studies, it is not possible to increase the difficulty through higher level of thinking, but the teacher has to emphasize the importance of the curriculum for real life situations more and devote more attention to students during teaching, explain steps, analyse their mistakes and keep them active. This is also in harmony with up-to date knowledge (Banchi \& Bell, 2008; Cetin-Dindar, 2012). 
Exploring the relation between motivation, cognition and academic achievement is a desirable element for pedagogical work with the current generation of students, so-called generation $\mathrm{Z}$. The links between these areas are of utmost importance for education and, above all, for developing education with students. As documented by international research, active cognitive approaches must be used in the learning process, providing information in a way that enables students to find out how they change their way of thinking, realize the usefulness of the information they receive, and build professional insight. Thus, students will be able to judge the facts critically and in a different perspective. It all makes students educated and prepared for fully-fledged not only professional life. These developmental trends have not got into the Czech economic education in the secondary stage yet, although teachers have conditions to implement popular models for the development of learning and thinking. It is not possible to present that individuals with the potential for absorption of an active learning process are not born and that there is a lack of those who could develop critical, creative thinking and be educated through the development of higher cognitive levels, as confirmed by the studies. The key to this is the awareness that all students can develop themselves and it is needed to educate them in time to form their personality and develop all of their potential abilities. Therefore, the researchers have researched which factors in the area of pedagogical competences of a teacher in secondary education affect students' school results and motivation in economic subjects, taking into account such factors leading to the active learning process and helping development of cognitive dimensions. The intellectual level and students' academic achievement were the chosen indicators to differentiate students.

Research has revealed a number of weak or critical places in pedagogical work with the average and above average intellectual level of Czech students of economic branches in secondary education. It will now be desirable to provide teachers with an insight into this knowledge through methodologies for pedagogical work with different student groups and above all for classifying students' abilities at the required cognitive levels. Because Bloom's taxonomy is still a recognized framework for assessing students' achievement, for teaching strategies, or supporting cognitive performance, the researchers also recommend that it can be used for classifying students and it will be incorporated into prepared methodologies.

\section{Acknowledgements}

This research was supported by the Project No. IGS VŠE F1/31/2015 and the Project VŠE No. IP 100040.

\section{References}

Al-Baddareen, Ghaith, S., \& Akour, M. (2015). Self-Efficacy, achievement goals and metacognition as predicators of academic motivation. Procedia Social and Behavioural Sciences, 19, 2068-2073.

Anderson, L. W., \& Kratwohl, P. (2001). A taxonomy for learning, teaching a assessing of educational objectives. New York: Longman.

Banchi, H., \& Bell, R. (2008). The many levels of inquiry. Science and Children, 46 (2), 26-29.

Barak, M., Ben-Chaim, D., \& Zoller, U. (2007). Purposely teaching for the promotion of higher-order thinking skills: A case of critical thinking. Research in Science Education, 37, 353-369.

Barrett, E., \& Moore, S. (2012). An introduction to problem-based learning. In Barret, E., \& Moore, S. (Eds.), New approaches to problem-based learning: Revitalizing your practice in higher education (pp. 3-17). New York: Routledge.

Berková, K., \& Krejčová, K. (2016). Effect of teachers' abilities on students' motivation with varying levels of intellectual abilities in economics. Journal on Efficiency and Responsibility in Education and Science, 9 (3), 81-87. 
Kateřina BERKOVÁ, Kristýna KREJČOVÁ, Alena KRÁLOVÁ, Pavel KRPÁLEK, Katarína KRPÁLKOVÁ KRELOVÁ, Dana KOLÁŘOVÁ. The conceptual four-sector model of development of the cognitive process dimensions in abstract visual thinking

\section{PROBLEMS \\ OF EDUCATION \\ IN THE $21^{\text {st }}$ CENTURY Vol. 76, No. 2, 2018}

138

Berková, K., \& Krpálek, P. (2017). Approaches to the development of cognitive process dimensions in financial literacy: An empirical study. Journal of International Studies, 10 (3), 173-188.

Berková, K., Králová, A., \& Krejčová, K. (2017). Application of the metacognitive strategy in economic education in the Czech Republic. Turkish Online Journal of Educational Technology, Special Issue for INTE 2017, 373-380.

Bissell, A. N., \& Lemons, P. P. (2006). A new method for assessing critical thinking in the classroom. BioScience, 56, 66-72.

Boekaerts, M. (2004). Motivation to learn. International bureau of education, General Conference of UNESCO. Geneva.

Broks, A. (2016) Systems theory of systems thinking: General and particular within modern science and technology education. Journal of Baltic Science Education, 15 (4), 408-410.

Cetin-Dindar, A. (2012). The effect of $5 E$ learning cycle model on eleventh grade students' conceptual understanding of acids and bases concepts and motivation to learn chemistry (Unpublished dissertation). Ankara: Middle East Technical University.

Crowe, A., Dirks, C., \& Wenderoth, M. P. (2008). Biology in Bloom: Implementing Bloom's taxonomy to enhance student learning in biology. CBE-Life Sciences Education, 7, 368-381.

Cubukcu, F. (2009). Metacognition in the classroom. Procedia Social and Behavioural Sciences, 1, 559563.

Dasgupta, P., \& David, P. (1994). Toward a new economics of science. Research Policy, 23 (5), 487-521.

Draper, N. R., \& Smith, H. (1998). Applied regression analysis. New York: Wiley.

Erduran, S., \& Jiménez, M. P. A. (2008). Argumentation in science education: Perspectives from classroom- based research. Dordrecht, Netherlands: Springer.

Forman, A.K. (2002). Videňský maticový test [Viennese matrices test] Prague: Testcentrum.

Duch, B. J., Groh, S. E., \& Allen, D. E. (2001). The power of problem-based learning. Sterling, VA: Stylus Publishers.

Granello, D. (2001). Promoting cognitive complexity in graduate written work: Using Bloom's taxonomy as a pedagogical tool to improve literature reviews. Counsellor Education \& Supervision, 40 (4), 292-308.

Gul, F., \& Shehzad, S. (2012). Relationship between metacognition, goal orientation and academic achievement. Procedia Social and Behavioural Sciences, 47, 1864-1868.

Cheng, M. F., Lin, J. L., Lin, S. Y., \& Cheng, Ch. H. (2017) Scaffolding middle school and high school students' modelling processes. Journal of Baltic Science Education, 16 (2), 207-217.

Jurečka, V., Hon, M., Jánošíková, I., Kolcunová, E., \& Spáčilová, L. (2013). Mikroekonomie [Microeconomics]. Prague: Grada Publishing.

Kirschner, P. J., Buckingham Shum, S. J., \& Carr, C. S. (2002). Visualising argumentation: Software tools for collaborative and educational sense-making. London: Springer-Verlag.

Liu, Z. K., He, J., \& Li, B. (2015) Critical and creative thinking as learning processes at top-ranking Chinese middle schools: Possibilities and required improvements. High Ability Studies, 26 (1), $139-152$.

Loužek, M. (2016). The economic approach to science. Prague Economic Paper, 25 (4), 494-506.

Mäki, U. (1992). Social conditioning in economics. In N. Marchi (Ed.), Post-Popperian Methodology of Economics. Recovering Practice (pp. 65 -104). Boston: Kluwer.

Nelson, C. E. (2008). Teaching evolution (and all of biology) more effectively: Strategies for engagement, critical reasoning, and confronting misconceptions. Integrative and Comparative Biology, 48, 213-225.

Newell, A., \& Simon, H. A. (1972). Human problem solving. Englewood Cliffs: Prentice Hall.

OECD. (2014). PISA 2012 Results: Students and money. Financial Literacy Skills for the 21st Century (Volume VI), PISA: OECD Publishing, 204p. Retrieved 20/08/2017. from: http://www.oecd.org/ pisa/keyfindings/PISA-2012-results-volume-vi.pdf/, referred on 2017-01-20.

Pascarella, E. T., \& Terenzini, P. T. (2005). How college affects students. A third decade of research. San Francisco, CA: Jossey-Bass.

Pasiar, L., Berková, K., Krejčová, K., Pavera, L., Čonková, A., \& Chmelárová, Z. (2015). Osobnost učitel'a $v$ ekonomickom vzdelávaní. [The personality of a teacher in economic education]. Bratislava: Ekonóm. 
Kateřina BERKOVÁ, Kristýna KREJČOVÁ, Alena KRÁLOVÁ, Pavel KRPÁLEK, Katarína KRPÁLKOVÁ KRELOVÁ, Dana KOLÁŘOVÁ. The conceptual four-sector model of development of the cognitive process dimensions in abstract visual thinking

Paul, R. W. (1992). Critical thinking: What, why, and how? New Directions for Community Colleges, 77, $3-24$.

Peirce, C. S. (1967). Note on the theory of the economy of research. Operations Research, 15 (4), 643 648.

Polanyi, M. (1962). The republic of science. Its political and economic theory. Minerva, 1 (1), 54-73.

Savin-Baden, M. (2004). Facilitating problem-based learning. Philadelphia, USA: Open University Press.

Steelová, J. L., Meredith, K. S., Temple, Ch., \& Walter, S. (1997). Co je kritické myšlení (vymezení pojmu a rámce $E-U-R$ ) [What is Critical Thinking (defining the concept and framework of $\mathrm{E}-\mathrm{R}-\mathrm{R}$ )]. Prague: Kritické myšlení [Critical Thinking].

Sternberg, J., \& Williams, W. (2010) Educational psychology. New Jersey: Pearson.

Subroto, W. T. (2015). Creative thinking development to foster economic creative: Evidence of State University of Surabaya. International Review of Management and Marketing, 5 (3), 108-113.

Tasci, G., \& Yugurdi, H. (2017). Biology teaching through self-regulated learning and cognitive structure: An analysis of the effect of learning strategies for cognitive development via latent growth model. Journal of Baltic Science Education, 16 (1), 20-31.

Taylor, T. L., \& Klein, R. M. (1998). On the causes and effects of inhibition of return. Psychonomic Bulletin and Review, 5, 625-643.

Tetteh, G. A., \& Sarpong, F. A. (2015). Influence of type of assessment and stress on the learning outcome. Journal of International Education in Business, 8 (2), 125-144.

Van Gelder, T. J., Bissett, M., \& Cumming, G. (2004). Cultivation expertise in informal reasoning. Canadian Journal of Experimental Psychology, 59, 142-152.

Watkins, D. A., \& Biggs, J. B. (2001). The paradox of the Chinese learner and beyond. In Watkins, D. A., \& Biggs, J. B. (Eds.), Teaching the Chinese learner: Psychological and pedagogical perspectives (pp. 3-23). Hong Kong: Comparative Education Research Centre.

Zoller, U. (2015). Research-based transformative science/STEM/STES/STESEP education for "sustainability thinking": From teaching to "know" to learning to "think". Sustainability, 7 (4), 4474-4491.

Received: January 30, 2018

Accepted: April 05, 2018

\begin{tabular}{|ll|}
\hline \multirow{3}{*}{ Kateřina Berková } & Ph.D., Assistant Professor at Department of Economic Teaching Methodol- \\
& ogy, Faculty of Finance and Accounting, University of Economics, Prague, \\
& Czech Republic. \\
& E-mail: katerina.berkova@vse.cz \\
\hline \multirow{3}{*}{ Kristýna Krejčová } & Ph.D., Assistant Professor at Department of Economic Teaching Methodol- \\
& ogy, Faculty of Finance and Accounting, University of Economics, Prague, \\
& Czech Republic. \\
& E-mail: kristyna.krejcova@vse.cz \\
\hline \multirow{3}{*}{ Alena Králová } & Ph.D., Assistant Professor at Department of Economic Teaching Methodol- \\
& ogy, Faculty of Finance and Accounting, University of Economics, Prague, \\
& Czech Republic. \\
& E-mail: kralova@vse.cz \\
\hline \multirow{3}{*}{ Pavel Krpálek } & Associate Professor at Department of Economic Teaching Methodology, \\
& Faculty of Finance and Accounting, University of Economics, Prague, Czech \\
& Republic. \\
E-mail: krpp01@vse.cz
\end{tabular}

PROBLEMS

OF EDUCATION

IN THE $21^{\text {st }}$ CENTURY

Vol. 76, No. 2, 2018

139 